\title{
Crop Water Production Functions-A Review of Available Mathematical Method
}

\author{
Manijeh Mahmoudzadeh Varzi ${ }^{1}$ \\ ${ }^{1}$ Department of Civil and Environmental Engineering, Colorado State University, Fort Collins, Colorado, USA \\ Correspondence: Manijeh Mahmoudzadeh Varzi, Department of Civil and Environmental Engineering, Colorado \\ State University, Campus Delivery 1372, Fort Collins, Colorado 80523-1372, USA. Tel: 1-970-491-1141. E-mail: \\ manimava@rams.colostate.edu
}

$\begin{array}{lc}\text { Received: January 22, } 2016 & \text { Accepted: February 25, } 2016 \quad \text { Online Published: March 15, } 2016 \\ \text { doi:10.5539/jas.v8n4p76 } & \text { URL: http://dx.doi.org/10.5539/jas.v8n4p76 }\end{array}$

\begin{abstract}
Crop water production function is the relationship between obtained marketable yield and the total amount of water used by plant through evapotranspiration. Different mathematical expressions have been derived from field experiments to predict yield knowing water use. Such expressions provide a powerful tool in water allocation optimization. However these functions are commonly confused with the relationship between available water and crop yield. This paper reviews functions that describe crop water production, the context they can be used for, and their strength and weakness.
\end{abstract}

Keywords: CWPF, yield response to water, evapotranspiration and crop yield, available water and yield, applied water and yield, deficit irrigation

\section{Introduction}

\subsection{Crop Water Production Function}

Water demand is increasing with urban and industrial growth. In many basins, all available sources of water are already developed and under use. Therefore, cities and industries look to agriculture for obtaining new water. With the transfer of agricultural water away from farms, crop production must be done under water scarcity. Crop response to water shortage is yield reduction. Yield reduction is followed by reduction in farming revenue, which jeopardizes the rural economy (Pritchett, Thorvaldson, \& Frasier, 2008). To predict the gravity of these changes, yield reduction due to water shortage must be quantified. Moreover, at the farm level, water can be used for production of different crops with different water requirements, yield productions, and yield prices. Water can also be used for other on- or off-farm activities. Therefore, optimizing water allocation in order to generate the maximum economic benefit from this limited resource becomes desirable.

Yield response to water can be explained by deriving crop water production functions (CWPFs). The CWPFs can be derived through expert opinion, field experiment, statistical analysis of survey data, or mathematical simulations based on observations (Young \& Loomis, 2014). The result can be presented as a mathematical function, table, or graph. The functional form is preferred by engineers and water planners because it can be directly used in optimization problems and decision support systems. This paper reviews the mathematical expressions developed to date that explain CWPF.

\subsection{Terminology and Concepts}

The total crop water requirement is the maximum amount of water that a crop can use productively when the soil water content is not limiting (Brouwer \& Heibloem, 1986). Crops mainly need water for cooling purposes; most of the root's water uptake is released back to the atmosphere through transpiration, and only a negligible fraction is retained for crop growth. In field experiments, partitioning transpiration from soil water evaporation is difficult. Therefore, in practice, evapotranspiration (ET) is measured or calculated. Evapotranspiration is the combination of two separate processes whereby water is lost from the soil surface by evaporation and from the crop by transpiration (Allen, Pereira, Raes, \& Smith, 1998). Therefore, "crop evapotranspiration" and "crop water requirement" are terms used interchangeably (Schneekloth \& Andales, 2009). Any amount of available water beyond ET is not consumed by the crop; therefore, CWPF is defined as the relationship between the obtained marketable yield and the total amount of water used by the crop through ET (Doorenbos \& Kasssam, 
1979). The United Nation's Food and Agricultural Organisation (FAO) has published Irrigation and Drainage Paper 56 [FAO56] for ET calculation. The procedure given in FAO56 is standardized by American Society of Civil Engineers (ASCE) (Allen et al., 2005) which is widely used for ET calculations. Kumar, Jat, and Shankar (2012) in their review paper discuss the theoretical background on ET terminology and calculation methods.

The amount of water consumed by the crop is ET, but since every system has some losses, an amount of water more than ET should be available to the crop. The difference between consumed water and available water (sometimes called applied water) is the system loss. Water is made available for crops through rainfall, irrigation, and residual soil moisture. Water consumed by the crop (or ET) is always less than the total of these three terms because of losses (deep percolation and surface runoff).

Since saving irrigation water is desired in water management, many researchers have tried to relate the amount of irrigation to yield. Results of such works are not applicable to other places, and are hardly even useful for future growing seasons in the same location because the amount of rainfall changes from year to year and location to location and because different soil types hold different amounts of water. Others have related amount of soil available water to yield. However, available water includes loss terms, which vary for different soils, field slopes, irrigation systems, and farm management practices. The useful practice would be relating yield to ET. Previous research shows that yield and ET are well-correlated and ET (i.e. water) is the main input to yield production (Tanner \& Sinclair, 1983), unless soil malnutrition is severe or pests and diseases are not controlled.

Irrigation is a way to supplement the water needs of crops and obtain higher yields. In times of scarcity, deficit irrigation or "the deliberate under-irrigation of the crop" (English, 1990) can be practiced. It is an on-farm strategy to cope with water scarcity. In this practice farmers save water by accepting some yield reduction. The promise is to use the saved water for other uses (Fereres \& Soriano, 2007) and increase the net economic income for example by increasing the land under cultivation (English \& Raja, 1996) or leasing water to off-farm demands. One reason for developing CWPFs is to be able to regulate deficit irrigation. For example Institute of Agriculture and Natural Resources in University of Nebraska-Lincoln have developed "Water Optimizer", a decision support tool for farmers. The tool is developed for Nebraska's conditions and uses CWPFs to define water allocation in order to obtain maximum economic benefit from available irrigation water. Another similar tool is "Crop Water Allocator" from Kansas State University which is developed for Kansas State Climate and crops (Klocke, Stone, Clark, Dumler, \& Briggeman, 2006). Both tools are free and available online.

In deficit irrigation both amount and timing of water stress are important because some crop growing stages are more sensitive to water shortage than others. The main crop growing stages, according to FAO33, are initial (from planting to $10 \%$ ground cover), vegetative (from $10 \%$ to $70 \%$ ground cover), reproduction (flowering and yield formation), and maturation (yield ripening). The initial and reproduction stages are particularly sensitive to water stress. During the initial stage crop is using water for germination and water shortage will prevent some of the seeds to germinate, reducing crop stand per area and severely affecting final yield. Water deficit during reproductive stage reduces number of grains and grain weight, therefore, decreases the yield (Tolk \& Howell, 2003; Zhang, 2003; Payero et al., 2005). The damage of water stress during these stages cannot be compensated later on. Therefore, CWPF models must include this aspect of yield-ET relationship.

\section{Evolution of Crop Water Production Function Models}

\subsection{De Wit's Equation}

In the first half of the twentieth century, scientists tried to find the relationship between yield and water use by growing plants in containers. According to Vaux and Pruitt (1983) the containers were covered to prevent evaporation from the soil surface and were weighed to define the transpiration. Analyzing these early studies, de Wit (1953) found a linear relationship between transpiration and total dry matter production as illustrated in Equation (1):

Where,

$$
P=m \frac{T}{E_{o}}
$$

$P$ is total dry matter production in kilograms per hectare;

$T$ is total transpiration during crop growing season in centimeters;

$E_{o}$ is average free water surface evaporation rate during growing season in centimeters per day;

$m$ is a crop factor having dimensions of kilogram per hectare per day.

He also found that Equation (1) can be simplified for humid conditions because the ratio of $T / E_{o}$ does not change 
appreciably when water is not limited and:

$$
\boldsymbol{P}=\boldsymbol{n T}
$$

Then, the crop factor $n$ has dimensions of kilograms per hectare. So he presented the general equation as:

$$
P=y T E_{0}^{-x}
$$

Where, $x=1$ and $y=m$ for locations with a large percentage of bright sunshine, and $x=0$ and $y=n$ in locations with small percentage of bright sunshine. He speculated that $\mathrm{x}$ can fall between zero and one for some climates but did not have enough data to prove it. Factors $m$ and $n$ depend only on the type of crop, provided that the soil nutrient level and/or soil excess water content are not hampering crop growth. Therefore, de Wit concludes that the same equations can be used for crops grown in the field.

Although de Wit's method was used for modeling plant yield as influenced by water (for example see Hanks, 1974), it has two main limitations. First the equation calculates total biomass production while only the marketable yield is interesting in an economic analysis. Besides, as mentioned earlier, separating crop transpiration from soil evaporation is not straight forward (Kool et al., 2014) and instead crop ET is defined. Therefore, this method is not used in practice. Later research showed that $y$ is not just crop dependent; experiments with corn gave different values of $y$ for the same experimental treatments (Tanner \& Sinclair, 1983). Moreover, some growing stages are more sensitive to shortage of water, but this method does not account for the effect of water stress timing. Nevertheless, de Wit's method is a valuable first step in quantifying yield-water relationship.

\subsection{Jensen's Equation}

In another approach Jensen (1968) related water stress to yield as follows:

$$
\frac{Y_{a}}{Y_{m}}=\prod_{i=1}^{n}\left(\frac{E T_{a}}{E T_{m}}\right)_{i}^{\lambda_{i}}
$$

Where,

$Y_{a}$ is the actual crop yield;

$Y_{m}$ is the maximum crop yield when soil water is not limiting;

$E T_{a}$ is the actual crop evapotranspiration;

$E T_{m}$ is the crop evapotranspiration when soil water is not limiting;

$i$ is the crop growing stage;

$\lambda_{\mathrm{i}}$ is the relative sensitivity of the crop to water stress during the stage of growth $i$ (unitless);

$n$ is the number of growth stages.

Inclusion of the maximum yield and the maximum ET, accounts for climate and soil variability so the sensitivity factor, $\lambda$, only depends on the type of crop. A greater $\lambda$ represents more sensitivity to drought. The equation accounts for sensitivity of the crop to different growing stages. Jenson considered three stages (emergence to boot, boot to milk, and milk to harvest) for sorghum, but in an experiment, the growing season can be divided into any number of stages to define desired $\lambda$ values. Because of the multiplicative structure of the equation, when $E T_{a}$ is zero in any one stage, the yield will be zero. Zero $E T_{a}$ means the crop is not transpiring and is dead, hence not producing yield. In his paper, Jensen used the term "water use" instead of ET. This may be why some researchers, have used available water in Equation (4) rather than ET while calculating $\lambda$ for different crops (such as Nairizi \& Rydzewski, 1977), which is not proper.

Crop relative sensitivity, $\lambda$, has been defined by experimentation for sorghum (Jensen, 1968), wheat (Zhang \& Oweis, 1999), corn (B. Zhang, Yuan, J. Zhang, \& Li, 2008), cotton, peanut, and soybean (Woli, Jones, Ingram, \& Hoogenboom, 2014). According to these studies, although, $\lambda$ value for a certain crop varies in different stages, for the entire growing season, it has a value close or equal to one, suggesting that yield has a linear relationship with ET.

\subsection{FAO's Equation}

Later, Doorenbos and Kassam (1979) analyzed results of several studies on the ET-yield relationship and introduced a yield response factor $(K y)$ in FAO Irrigation and Drainage Paper 33 [FAO33] and suggested the following linear function:

$$
1-\frac{Y_{a}}{Y_{m}}=K y\left(1-\frac{E T_{a}}{E T_{m}}\right)
$$


Where, $1-Y_{a} / Y_{m}$ is the relative crop yield decrease and $1-E T_{a} / E T_{m}$ is the relative evapotranspiration deficit. Crops with higher $K y$ are more sensitive to water deficit. Equation (5) is very similar to an equation derived by Stewart, Hagan, and Pruitt (1976), for corn, grain sorghum, and pinto beans.

To account for different growing stages Equation (5) is rewritten as:

$$
1-\frac{Y_{a}}{Y_{m}}=\sum_{i=1}^{n} K y_{i}\left(1-\frac{\left(E T_{a}\right)_{i}}{\left(E T_{m}\right)_{i}}\right)
$$

The same paper provides $K y$ for entire growing season as well as $K y$ for each growing stage of 26 crops. This equation has been extensively used in planning deficit irrigation. An open-access software, AquaCrop, has been developed based on this method (Raes, Steduto, Hsiao, \& Fereres, 2009; Steduto, Hsiao, Raes, \& Fereres, 2009).

Equation (6) predicts some yield when $E T_{a}$, at least in one stage, is non-zero. However, $E T_{a}=0$ at any stage means no transpiration at which point the crop dies. Therefore, this equation overestimates yield production. Conversely, Zwart and Bastiaanssen's (2004) review of 84 publications shows that the amount of $Y_{m} / E T_{m}$ for wheat, rice, cotton and corn exceeds those reported by Doorenbos and Kassam in all experiments. That is, Equation (6) underestimates yield production. Possibly the underestimating factors cancel out the effect of overestimating factor because about $80 \%$ to $85 \%$ of observations in different locations confirm that crop yield reduction can be described with the FAO method and $K y$ values given in FAO33 (Raes, Geerts, Kipkorir, Wellens, \& Sahli, 2006).

\subsection{Shape of CWPF Curve}

More than one hundred years of experimentation shows that ET and yield are linearly related, over the growing season (Vaux \& Pruitt, 1983). This is reflected in Jensen's and FAO's equations. New research also supports the linearity of CWPF (for example Schneekloth, Klocke, Hergert, Martin, \& Clark, 1991; Payero et al., 2005 both on soybean). This is especially true for forage crop in which yield is a larger part of crop biomass (Smeal, Gregory, \& Arnold, 1992; Sanden, Putnam, \& Hanson, 2007 both on alfalfa).

Furthermore, experience shows that a minimum ET is necessary for a crop to start yield production; therefore, ET-yield line intercepts the ET axis at a value greater than zero. Yet, this characteristic is not captured by any of the equations developed so far. In Jensen's equation, zero yield results in zero ET and in FAO's equation, it renders some yield even when ET is equal to zero. Although both equations describe yield reduction due to ET deficit within an acceptable range (Raes et al., 2006), they do not have realistic predictions for the minimum ET required for the start of yield production.

\section{Available Water and Crop Yield Relationship}

As explained in the terminology section, the relationship between available water and yield is not transferable. However, practically, available water is the variable used in irrigation and water management because the losses are part of any irrigation system. Available water is easier to measure and more tangible for farm managers. Therefore, many studies relate available water to crop yield. Some literature (Solomon, 1985; English, 1990) even has defined CWPF as the relationship between "water available for crops" and crop yield. This definition is not used in this paper, but the relationship is described here for clarification and future discussion.

\subsection{General Form of Available Water-Yield Curve}

The available water-yield relationship [AWYR] has the typical form illustrated in Figure 1. A minimum amount of water needs to be available for a crop to start yield production. After this minimum amount the crop is still under water stress but yield production starts. The water applied to crop by rainfall and irrigation is lower than crop requirement and nearly all of it is stored in the root zone and efficiency is generally high. Therefore, crop yield increases linearly with an increased amount of available water up to about $50 \%$ of the water application requirement [WAR]. As amount of available water approaches adequacy, losses occur due to the non-uniformity and imprecision of the system and soil inhomogeneity. Then the function takes a curvilinear shape. After the total crop water requirement is reached, applying more water may decrease crop yield due to water logging, absence of air in the root zone, nutrient leaching, and plant diseases (English, 1990; Solomon, 1985). The increasing limb (Zone I in Figure 1) and the decreasing limb (Zone II) of the curve are asymmetric because they are the result of different mechanisms. In Zone I, limited water results in increased soil water tension so that the crop water uptake is reduced. The crop responds to water stress with stomatal closure, which means less photosynthesis and less yield production. In agricultural water management, only Zone I is interesting, so most of the experimentally derived curves only describe Zone I. 


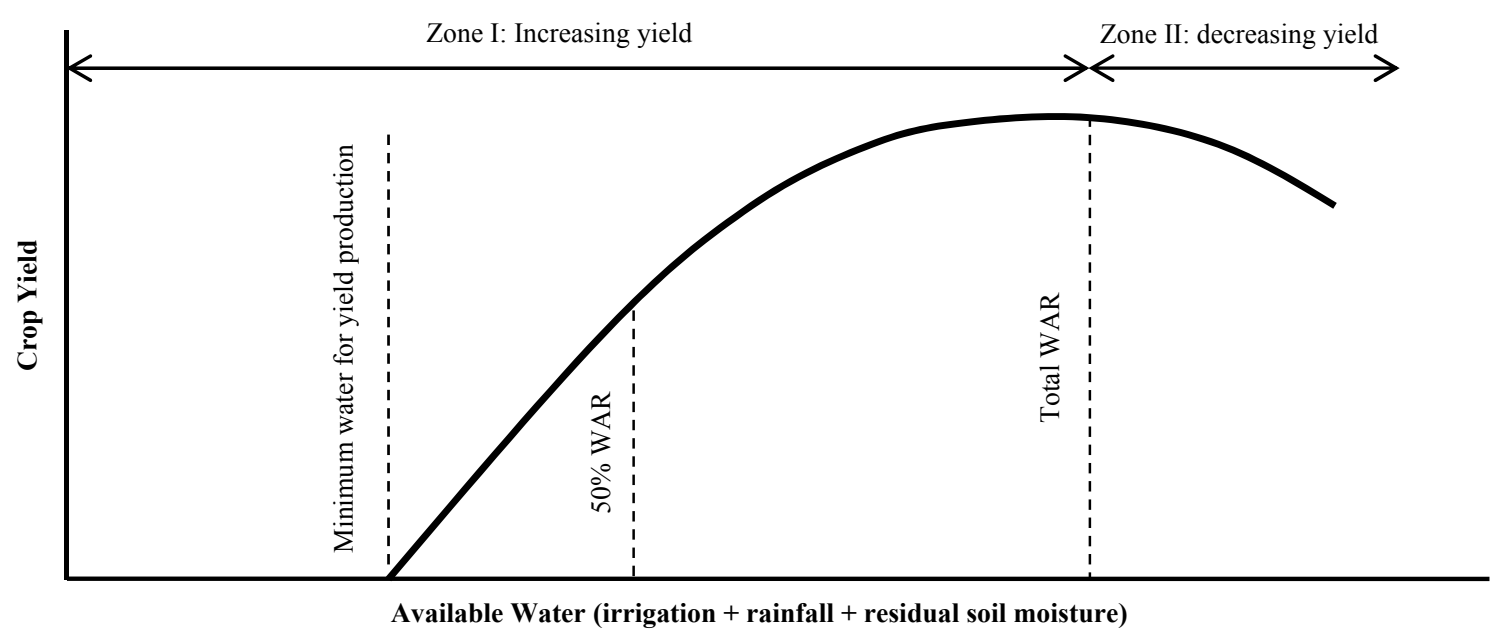

Figure 1. General form of available water - yield curve (adapted from English, 1990)

Note. $\mathrm{WAR}=$ Water Application Requirement.

\subsection{Models for Describing Available Water and Yield Relationship}

Different functional forms have been used to describe the curve of Figure 1. Soybean yield (Yaron, 1967; Klocke, Eisenhauer, Specht, Elmore, \& Hergert, 1989) was described by a quadratic function as:

$$
Y=a+b(a w)+c(a w)^{2}
$$

where $a w$ is the available water and $a, b$, and $c$ are regression coefficients depending on crop type. This function, however, is symmetric around maximum yield. Solomon (1985) suggested a quartic equation based on the results of several field experiments for the 37 crops that he found in literature as follows:

$$
Y=a_{0}+a_{1}(R A W)+a_{2}(R A W)^{2}+a_{3}(R A W)^{3}+a_{4}(R A W)^{4}
$$

So that the asymmetry of Zone I and Zone II can be incorporated into the function. In Equation (8) $R A W$ is the relative available water or "the ratio of available water to that value of available water that corresponds to the maximum yield" (Solomon, 1985). Solomon determined $a_{0}$ to $a_{4}$ (regression coefficients) for each of the 37 crops for low, medium, and high yield sensitivity to excess water. The function sometimes returns negative yields for $R A W$ below 0.1 , and sometimes, it predicts increasing yields in zone II.

Hexem and Heady (1978) gave an extensive report of a collaborative experimentation on the effect of agricultural inputs and soil characteristics on crop yield. The study was conducted on corn (grain and silage), cotton, wheat, sugar, and beets in Colorado, Texas, Kansas, Arizona, California, and Oregon from 1968 to 1971. Study variables were plant population, depth of available water, amount of nitrogen applied per unit of area, soil $\mathrm{pH}$, soil electrical conductivity, soil available water holding capacity (in upper $1.2 \mathrm{~m}$ of soil) and depth of pan evaporation over the silking period (defined as critical period). They defined a generalized equation relating the independent variables to the yield for each of the five crops. Since, in this study, the amount of available water (as opposed to the amount of consumed water or ET) was measured, the results are not transferable to other locations. In fact, in order to increase the correlation coefficient, they had to define an extra equation per crop for some of their experimental locations.

These kinds of functions, although informative, must not be used for yield prediction. A better practice would be defining yield based on ET and then accounting for system losses.

\section{Discussion and Conclusion}

Many variables are used to determine the relationship between water and crop yield; these are ET, available water, and amount of irrigation. Only ET has a physiological relationship with the yield. Available water contains losses in the field and irrigation ignores the effect of rainfall on the yield. Thus, field experiments need to aim to define the relationship between ET and yield. Such results are transferable.

The literature review reveals substantial confusion between CWPF and AWYR because authors have used the same term for different variables or have described the same variable in different words. Sometimes available 
water is used in place of ET in Jenson's or FAO's equations, and other times the ET component in CWPF is interpreted as available water. It is important to understand the distinction between these two functions.

Evidence exists that AWYR is convex (Vaux \& Pruitt, 1983), as described by Solomon's equation and earlier works. The convex shape of the curve means that the marginal yield production per added unit of water decreases as the amount of available water increases (the derivative of the function is negative). Therefore, crop water use efficiency increases with deficit irrigation and indicates a potential economic benefit to deficit irrigation. Yet again, most field experiments indicate that CWPF has a linear shape for the entire growing season, based on which the Jensen and FAO equations were developed. The linearity of CWPF, if factual, implies that the marginal yield production per added unit of water is constant and water use efficiency does not change with deficit irrigation.

Because of the curvilinearity of AWYR, many researchers (for example English, 1990 or Smith, 2011) have recommended the practice of deficit irrigation as an on-farm water-saving method. On the other hand, linearity of CWPF does not justify such a practice because any reduction in ET has a constant amount of yield reduction. The difference between CWPF and AWYR is due to the loss terms; therefore, if the system losses can be avoided, AWYR curve approaches CWPF curve. This can be done by employing more efficient irrigation systems. So deficit irrigation has the same effect as increasing irrigation efficiency. In absence of losses and assuming a linear CWPF, there is no justification for deficit irrigation. Thus, deficit irrigation should only be practiced when increasing on-farm irrigation efficiency is not viable (due to financial, technological, or institutional constraints). Nevertheless, CWPF is a powerful tool for choosing crops in times of water scarcity.

Research on the shape of CWPF is not conclusive and these equations need to be validated against field data. Furthermore, they need to reflect the fact that yield production does not start until the crop evapotranspires a minimum amount of water. In times of water scarcity, the minimum required ET by the crop is an important factor in irrigation planning and decision making.

Although FAO's and Jensen's equations are widely used and relatively reliable, there is still value in field experiments to develop CWPF for different crops. There are several studies on common crops like wheat, corn, cotton, and soybeans, and research on these crops are still ongoing (for example see Trout, 2012). It will be valuable to define CWPF for other crops so farmers and water managers have more options when choosing crops under water scarcity. There is still need for more research in order to understand crop physiological responses to water shortage (Morison, Baker, Mullineaux, \& Davies, 2007) and employing molecular genetic approaches to increase crop water productivity.

\section{References}

Allen, R. G., Periera, L. S., Raes, D., \& Smith, M. (1998). Crop evapotranspiration (Guidelines for computing crop water requirements). Rome: Food and Agriculture Organization of the United Nations.

Allen, R. G., Walter, I. A., Elliott, R., Howell, T., Itenfisu, D., \& Jensen, M. (2005). The ASCE Standardized Reference Evapotranspiration Equation. Reston, VA: American Society of Civil Engineers (ASCE).

Brouwer, C., \& Heibloem, M. (1986). Irrigation Water Management: Irrigation Water Needs. Rome: Food and Agriculture Organization of the United Nations.

Doorenbos, J., \& Kasssam, A. H. (1979). Yield Response to Water. Rome: Food and Agriculture Organization of the United Nations.

English, M. J. (1990). Deficit Irrigation. I: Analytical Framework. Journal of Irrigation and Drainage Engineering, 116, 399-412. http://dx.doi.org/10.1061/(ASCE)0733-9437(1990)116:3(399)

English, M. J., \& Raja, S. N. (1996). Perspectives on deficit irrigation. Agricultural Water Management, 32, 1-14. http://dx.doi.org/10.1016/S0378-3774(96)01255-3

English, M. J., Solomon, K. H., \& Hoffman, G. J. (2002). A Paradigm Shift in Irrigation Management. Journal of $\begin{array}{llll}\text { Irrigation and Drainage } & \text { 267-277. }\end{array}$ http://dx.doi.org/10.1061/(ASCE)0733-9437(2002)128:5(267)

Fereres, E., \& Soriano, M. A. (2007). Deficit Irrigation for Reducing Agricultural Water Use. Journal of Experimental Botany, 58(2), 147-159. http://dx.doi.org/10.1093/jxb/erl165

Hanks, R. J. (1974). A model for predicting plant yield as influenced by water use. Agronomy Journal, 66(5), 660-664. http://dx.doi.org/10.2134/agronj1974.00021962006600050017x

Sanden, B., Putnam, D., \& Hanson, B. (2007). Forage production strategies with limited water supplies. 
Proceedings of $37^{\text {th }}$ California Alfalfa Symposium. Monterey, CA, USA.

Hexem, R. W., \& Heady, E. O. (1978). Water production functions for irrigated agriculture. Ames, IA: The Iowa State University Press.

Jensen, M. E. (1968). Water Consumption by Agricultural Plants. In T. T. Kozlowski (Ed.), Water Deficits and Plant Growth (Vol. 2, pp. 1-22). New York, NY: Academic Press.

Klocke, N. L., Eisenhauer, D. E., Specht, J. E., Elmore, R. W., \& Hergert, G. W. (1989). Irrigating soybeans by growth stages in Nebraska. Applied Engineering in Agriculture, 5(3), 361-366. http://dx.doi.org/10.13031/2013.26528

Klocke, N. L., Stone, L. R., Clark, G. A., Dumler, T. J., \& Briggeman, S. (2006). Water allocation model for limited irrigation. Applied Engineering in Agriculter, 22(3), 381-389. http://dx.doi.org/10.13031/2013.20458

Kool, D., Agam, N., Lazarovitch, N., Heitman, J. L., Sauer, T. J., \& Ben-Gal, A. (2014). A review of approaches for evapotranspiration partitioning. Agricultural and Forest Meteorology, 184, 56-70. http://dx.doi.org/10.1016/j.agrformet.2013.09.003

Kumar, R., Jat, M. K., \& Shankar, V. (2012). Methods to estimate irrigation reference crop evapotranspiration-A review. Water Science \& Thecnology, 66(3), 525-535. http://dx.doi.org/10.2166/wst.2012.191

Nairizi, S., \& Rydzewski, J. (1977). Effects of Dated Soil Moisture Stress on Crop Yields. Experimental Agriculture, 13(1), 51-59. http://dx.doi.org/10.1017/S0014479700007602

Payero, J. O., Melvin, S. R., \& Irmak, S. (2005). Response of soybean to deficit irrigation in the semi-arid environment of west-central Nebraska. Transactions of the ASAE, 48(6), 2189-2203. http://dx.doi.org/10.13031/2013.20105

Pritchett J., Thorvaldson, J., \& Frasiere, M. (2008). Water as a Crop: Limited Irrigation and Water Leasing in $\begin{array}{lllll}\text { Colorado. } & \text { Review of }\end{array}$ http://dx.doi.org/10.1111/j.1467-9353.2008.00417.x

Raes, D., Geerts, S., Kipkorir, E., Wellens, J., \& Sahli, A. (2006). Simulation of yield decline as a result of water stress with a robust soil water balance model. Agricultural Water Management, 81, 335-357. http://dx.doi.org/10.2134/agronj2008.0140s

Raes, D., Steduto, P., Hsiao, T. C., \& Fereres, E. (2009). AquaCrop-The FAO Crop Model for Predicting Yield Response to Water: II. Main algorithms and soft ware description. Agronomy Journal, 101(3), 438-447. http://dx.doi.org/10.2134/agronj2008.0140s

Schneekloth, J. P., Klocke, N. L., Hergert, G. W., Martin, D. L., \& Clark, R. T. (1991). Crop rotations with full and limited irrigation and dryland management. Transactions of ASAE, 34(6), 2372-2380. http://dx.doi.org/10.13031/2013.31882

Schneekloth, J., \& Andales, A. (2009). Seasonal Water Needs and Opportunities for Limited Irrigation for Colorado Crops. Fort Collins, CO: Colorado State University Extension.

Smeal, D., Gregory, E. J., \& Arnold, R. N. (1992). Interseasonal variability in the water use-production function of alfalfa. Journal of Production Agriculture, 5, 576-580. http://dx.doi.org/10.2134/jpa1993.0576

Smith, S. W. (2011). Strategies for Limited and Deficit Irrigation to Maximize On-Farm Profit Potential in Colorado's South Platte Basin (Doctoral dissertation, Colorado State University library).

Solomon, K. H. (1985). Typical Crop Water Production Functions. American Society of Agricultural Engineers winter meeting. Chicago, IL.

Steduto, P., Hsiao, T. C., Raes, D., \& Fereres, E. (2009). AquaCrop-The FAO crop model to simulate yield response to water: I. Concepts and underlying principles. Agronomy Journal, 101, 426-437. http://dx.doi.org/10.2134/agronj2008.0139s

Stewart, J. I., Hagan, R. M., \& Pruitt, W. O. (1976). Production functions and predicted irrigation programmes for principal crops as required for water resources planning and increased water use efficiency. Washington DC, WA: U.S. Department of Interior.

Tanner, C. B., \& Sinclair, T. R. (1983). Efficient water use in crop production: research or re-search? In H. M. Taylor, J. R. Wayne, \& S. R. Thomas (Eds.), Limitations to efficient water use in crop production (pp. 1-27). Madison, WI: American Society of Agronomy, Crop Science Society of America, Soil Science Society of 
America.

Tolk, J. A., \& Howell, T. A. (2003). Water use efficiencies of grain sorghum grown in three USA Sothern Great Plains soils. Agricultural Water $\quad$ Management, 111. http://dx.doi.org/10.1016/S0378-3774(02)00157-9

Trout, T. J. (2012). Water production functions for central plains crops. Proceedings of the 24th Annual Central Plains Irrigation Conference. Colby, Kansas: Kansas State University. http://dx.doi.org/10.13031/2013.35820

Vaux, Jr. H. J., \& Pruitt, W. O. (1983). Crop-water production functions. In D. Hillel (Ed.), Advances in irrigation (Vol. 2, pp. 61-97). Orlando, FL: Academic Press. http://dx.doi.org/10.1016/b978-0-12-024302-0.50009-6

Wit, C. T. D. (1958). Transpiration and crop yields. Wageningen, The Netherlands: Institute of Biological and Chemical Research on Field Crops and Herbage.

Woli, P., Jones, J. W., Ingram, K. T., \& Hoogenboom, G. (2014). Predicting Crop Yields with the Agricultural Reference Index for Drought. Journal of Agronomy and Crop Science, 200, 163-171. http://dx.doi.org/10.1111/jac.12055

Yaron, D. (1967). Empirical Analysis of the Demand for Water by Israeli Agriculture. Journal of Farm Economics, 49(2), 461-473. http://dx.doi.org/10.1007/978-1-4615-0899-1_3

Young, R. A., \& Loomis, J. B. (2014). Determining the economic value of water: Concepts and methods. Abingdon, Oxon: RFF Press. http://dx.doi.org/10.4324/9781936331703

Zhang, H., \& Oweis, T. (1999). Water-yield relations and optimal irrigation scheduling of wheat in the Mediterranean region. Agricultural Water Management, $195-211$. http://dx.doi.org/10.1016/S0378-3774(98)00069-9

Zhang, H. (2003). Improving Water Productivity through Deficit Irrigation: Examples from Syria, the North China Plain and Oregon, USA. In J. W. Kijne, R. Barker, \& D. Molden (Eds.), Water Productivity in Agriculture: Limits and Opportunities for Improvement. Colombo, Sri Lanka: International Water Management Institute. http://dx.doi.org/10.1079/9780851996691.0301

Zhang, B., Yuan, S., Zhang, J., \& Li, H., (2008). Study of corn optimization irrigation model by genetic algorithms. In IFIP International Federation for Information Processing, In D. Li (Ed.), Computer and Computing Technologies in Agriculture (Vol. 1, pp. 121-132). Boston, MA: Springer. http://dx.doi.org/10.1007/978-0-387-77251-6

Zwart, S. J., \& Bastiaanssen, W. G. M. (2004). Review of measured crop water productivity values for irrigated wheat, rice, cotton and maize. Agricultural Water Management, 69, 115-133. http://dx.doi.org/10.1016/j.agwat.2004.04.007

\section{Copyrights}

Copyright for this article is retained by the author(s), with first publication rights granted to the journal.

This is an open-access article distributed under the terms and conditions of the Creative Commons Attribution license (http://creativecommons.org/licenses/by/3.0/). 